\title{
IMPLEMENTASI PEMBIAYAAN MURABAHAH (STUDI KASUS WARUNG MIKRO BANK SYARIAH MANDIRI CABANG BOJONEGORO )
}

\author{
Bakhtiyar Arifin \\ Warsidi \\ Universitas Muhammadiyah Surabaya \\ Email : bakh2arifin@gmail.com
}

\begin{abstract}
One of the segmentation of Bank Syariah Mandiri to distribute financing to micro segment is that the warung micro aims to provide convenience to the micro enterprise in obtaining additional capital to expand its business, although it does not close to provide financing to customer who does note have micro enterprises.

This research uses qualitative research to know how the implementation of Murabahah financing on sharia bank independent of warung micro segment in practice and theory. Is the murabahah contract that is used in accordance with the fatwa of The National Sharia Council Indonesia Counsil of Religious Scholars in meeting the needs of the cusmoter to increase working capital.

The finding in the field that the contract used was a hybrid contract between murabahah and wakalah contract. So that presence of warung mikro bank syariah mandiri felt very beneficial to the customers in gaining capital increase for its business development easy and sharia.

The result of this study concluded that the contract and process carried out by the Warung Mikro Bank Syariah Mandiri Bojonegoro already in accordance with the applicable regulations in Indonesia is in accordance with the fatwa of the National Sharia Council Indonesia Counsil of Religious Scholars No. 04/DSN-MUI/IV/2000 on the financing of Murabahah ang implementation of murabahah financing. It is reflected in the filing process until the agreement between the bank and the customer.
\end{abstract}

Keywords: Murabahah, Warung Mikro Bank Syariah mandiri, Murabahah Working Capital.

\section{PENDAHULUAN}

Salah satu pendorong semakin berkembangnya perekonomian, karena bank syariah membuat orang Islam ikut tergerak dalam ekonomi dengan sistem ekonomi Islam. Ekonomi Islam tidak hanya bertujuan untuk memperoleh keuntungan materiil namun juga bertujuan untuk kemaslahatan dunia serta akhirat. Ekonomi Islam dengan alat ekonominya yang berupa bank syariah mencoba menjawab tantangan melawan riba'.
Menurut UU No. 10 Tahun 1998

Bank umum Syariah adalah bank umum yang melaksanakan usaha berdasarkan prinsip Syariah yang dalam kegiatannya memberikan jasa dalam lalu lintas pembayaran. Dijelaskan lebih lanjut pada UU tersebut Prinsip Syariah adalah aturan perjanjian berdasarkan hukum Islam antara bank dengan pihak lain untuk menyimpan dana dan atau pembiayaan kegiatan usaha, atau kegiatan lainnya yang dinyatakan sesuai dengan Syariah. Bank umum Syariah sebagai salah satu lembaga keuangan 
yang memiliki fungsi dalam menghimpun dana masyarakat dan menyalurkan dana masyarakat. Dalam kegiatan operasionalnya bank Syariah memiliki perbedaan dengan bank konvensional yaitu bank Syariah menggunakan istilah yang disebut dengan akad. Akad adalah pertalian antara ijab dan Kabul sesuai dengan kehendak Syariah yang menimbulkan akibat hukum pada objeknya. ${ }^{1}$

Salah satu akad yang digunakan pada kegiatan financing atau lending pada bank Syariah yaitu akad Murabahah. Murabaḥah adalah bentuk dari jual beli tertentu yang mengharuskan penjual menyatakan biaya perolehan barang, terdiri dari harga barang dan biaya lain yang diperlukan untuk memperoleh barang tersebut, dan tingkat keuntungan (margin) yang diinginkan ${ }^{2}$. Dalam perbankkan akad murabahah ini bank menyediakan barang permintaan dan menjualnya kembali kepada nasabah dengan pembayaran secara angsuran dalam jangka waktu yang telah disepakati . Berdasarkan data Otoritas Jasa keuangan (OJK) pembiayaan Murabahah mendominasi jumlah pembiayaan pada bank Syariah, yaitu mencapai porsi hampir $50 \%$ dari total pembiayaan yang disalurkan. Dominasi pembiayaan murabahah ini terjadi karena pembiayaan ini memiliki kecenderungan risiko yang lebih kecil dan lebih aman bagi pihak bank maupun nasabah.

Bank Syariah Mandiri adalah Bank Umum Syariah yang dalam melaksanakan kegiatan usahanya berdasarkan prinsip-prinsip syariah Islam. Bank Syariah Mandiri adalah salah satu anak perusahaan dari Bank

$1 \quad$ Nasroen Haroen, Fiqh Muamalah, Gaya Media Pratama, Jakarta, 2000, hlm. 97

$2 \quad$ Ascarya, Akad dan Produk Bank Syariah (Jakarta: PT Raja Grafindo, 2011), 82.
BUMN yang didirikan pada tanggal 1 November 1999 sebagai respon atas diberlakukannya UU No. 10 tahun 1998, yang memberi peluang bank umum untuk melayani transaksi Syariah (dual banking system). Kegiatan Bank Syariah Mandiri sebagaimana bank pada umumnya yaitu adanya kegiatan pengumpulan dana atau funding dan penyaluran pembiyaan atau financing. Pada segmen mikro Bank Syariah Mandiri memiliki unit divisi yang disebut "Warung Mikro". Divisi ini menangani pembiayaan khusus untuk segmen mikro yang menyediakan pembiayaan hingga batas maksimal 200 juta. Secara khusus segmen ini pembiyaan yang banyak disalurkan adalah pembiayaan modal kerja walaupun tidak menutup kemungkinan juga melayani untuk pembiyaan konsumtif. Dari jurnal yang penulis baca yaitu jurnal dari Ahmad Saifurriza Effasa dan Furi Asfiayatul Ain yang berjudul Faktor-Faktor yang mempengaruhi Rendahnya Minat Pedagang Muslim dalam menggunakan Jasa Bank Syariah Mandiri KC Sumberrejo Bojonegoro menyimpulkan bahwa salah satu faktornya adalah kurangnya Informasi masyarakat tentang alur dan penerapan akad Syariah di bank Syariah dan persepsi masyarakat tentang perbankan syariah, yaitu tidak ada perbedaan dalam praktik antara bank Syariah dengan bank konvensional. ${ }^{3}$ Hal ini mengakibatkan pasar perbankkan Syariah di Bojonegoro masih belum bisa mengalahkan dominasi bank konvensional. Dari hasil observasi di Bank Syariah Mandiri cabang

3 Effasa Ahmad Saifurriza,Furi

Asfiayatul Ain. 2019. Faktor-faktor yagn memperngaruhi rendahnya minat pedagang muslim dalam menggunakan jasa bank Syariah mandiri kc Sumberrejo Bojonegoro. Gema Ekonomi Jurnal Fakultas Ekonomi, 8(1). 
Bojonegoro segmen warung mikro bahwasannya akad pembiayaan yang disalurkan sebagian besar adalah pembiayaan modal kerja untuk membantu pedagang mikro untuk mengembangkan usahanya. Lebih lanjut dari hasil observasi bahwa akad yang digunakan pada pembiayaan adalah akad Murabahah.

Berdasarkan uraian diatas penulis melakukan penelitian secara langsung di PT bank syariah Mandiri cabang Bojonegoro tentang Implementasi Pembiayaan Murabahah. Dengan hasil penelitian ini diharapkan dapat memberikan Informasi tambahan untuk masyarakat Bojonegoro tentang alur dan proses pembiayaan mikro Syariah Mandiri dengan akad Murabahah yang sudah sesuai dengan ketentuan Syariah.

\section{TINJAUAN PUSTAKA}

Penelitian yang dilakukan oleh Desi Nurhabibah Program Pasca Sarjana Universitas Islam Negeri Raden Intan Lampung tahun 2018 dengan judul : "Implementasi Akad Murabahah pada Produk Pembiayaan Pertanian di BMT As- Syafi'iyah Kabupaten Pringsewu dan BMT Al- Hasanah Kabupaten Lampung Selatan Dalam perspektif Ekonomi Islam"4. Penelitian tersebut berfokus pada penerapan akad Murabahah yang disalurkan kepada para petani dalam memenuhi kebutuhan pada bidang pertanian seperti menyediakan bibit,pupuk obat-obatan dan kebutuhan pertanian lainnya.

Penelitian yang dilakukan oleh Sholihatin Khofsah Program Pasca

\footnotetext{
$4 \quad$ Nurhabibah Desi, Implementasi Akad Murabahah pada Produk Pembiayaan Pertanian di BMT As- Syafi'iyah Kabupaten Pringsewu dan BMT Al- Hasanah Kabupaten Lampung Selatan Dalam perspektif Ekonomi Islam .Tesis . Program Pasca Sarjana Universitas Islam Negeri Raden Intan Lampung Tahun 2018
}

Sarjana Universitas Islam Negeri Maulana Malik Ibrahim Malang tahun 2017 dengan judul : “ Implementasi Pembiayaan Murabahah bil Wakalah Sebagai Upaya untuk Meningkatkan Ekonomi Peternak Sapi di BMT AlHijrah Kan Jabung". 5 Penelitian tersebut memfokuskan tentang akad hybrid yaitu penggabungan dua akad menjadi satu antara akad murabahah dan akad wakalah dalam memenuhi kebutuhan peternak sapi memperoleh sapi sesuai keinginan peternak.

Jurnal Ilmiah yang ditulis oleh Kiki Priscilia Ramadhani jurusan Ilmu Ekonomi Fakultas Ekonomi dan Bisnis Universitas Brawijaya Malang tahun 2014 dengan judul Analisis Kesyariahan Penerapan Pembiayaan Murabahah (studi kasus PT. Bank Pembiayaan Rakyat Syariah xxx di Kota Mojokerto). ${ }^{6}$ Penelitian ini mengangkat tentang proses dan prosedur dalam penerapan pembiayaan murabahah di BPRS di kota Mojokerto. Pembiayaan murabahah yang disalurkan untuk kebutuhan konsumtif, investasi maupun modal kerja di teliti apakah sudah sesuai dengan ketentuan Syariah yang berlaku ataukah tidak.

\section{KERANGKA TEORI}

\section{Pembiayaan}

Pembiayaan (Financing) Menurut Muhammad adalah pendanaan yang diberikan oleh suatu pihak kepada pihak

\footnotetext{
$5 \quad$ Khofsah Sholihatin, Implementasi Pembiayaan Murabahah bil Wakalah Sebagai Upaya untuk Meningkatkan Ekonomi Peternak Sapi di BMT Al-Hijrah Kan Jabung. Tesis. Program Pasca Sarjana Universitas Islam Negeri Maulana Malik Ibrahim Malang tahun 2017

$6 \quad$ Ramadhani Kiki Priscilia, Analisis Kesyariahan Penerapan Pembiayaan Murabahah (studi kasus PT. Bank Pembiayaan Rakyat Syariah xxx di Kota Mojokerto). Jurnal. Jurusan Ilmu Ekonomi Fakultas Ekonomi dan Bisnis Universitas Brawijaya Malang tahun 2014.
} 
lain untuk mendukung investasi yang telah direncanakan, baik dilakukan sendiri maupun lembaga. ${ }^{7}$ Pembiayaan dalam bentuk usahanya yang meliputi pembiyaan dengan prinsip jual-beli (Murabahah, salam, istishna), pembiyaan dengan prinsip sewa yaitu ijarah (sewa murni) dan ijarah muntahiya bittamlik (sewa beli), pembiayaan dengan prinsip bagi hasil (musyarakah, mudharabah), akad pelengkap yaitu al-kafalah, al-hawalah, al-qardh dan ar-rahn.

\section{Murabahah}

Murabahah menurut ulama Utsmani merupakan salah satu bentuk jual beli yang mengharuskan penjual memberikan Informasi kepada pembeli tentang biaya-biaya yang dikeluarkan untuk mendapatkan komoditas (harga pokok pembelian) dan tambahan profit yang diinginkan yang tercermin dalam harga jual. Murabahah menekankan adanya pembelian komoditas berdasarkan pesanan dan proses penjualan kepada konsumen dengan harga jual yang merupakan akumulasi dari biaya beli ditambah profit yang diinginkan. Terkait dengan bank perlu dijelaskan untuk menerangkan tentang harga beli dan tambahan keuntungan yang diinginkan kepada nasabah. Dalam konteks pembiayaan murabahah ini, bank Syariah tidak meminjamkan uang kepada nasabah untuk membeli komoditas tertentu, tetapi pihak banklah yang berkewajiban untuk membelikan komoditas pesanan nasabah dari pihak ketiga dan kemudian menjualnya kembali kepada nasabah sesuai dengan harga yang telah disepakati. Landasan hukum akad Murabahah adalah Al Quran surat Albaqarah ayat 275 :

\footnotetext{
${ }^{7}$ Muhammad, Manajemen Pembiyaan Bank Syariah, (Yogyakarta: YKPN, 2005), hal 17
}

Di Indonesia ketentuan murabahah dapat dijabarkan dari beberapa ketentuan yaitu dalam fatwa DSN-MUI No. 04/DSNMUI/IV/2000 yang berbunyi :

1) Ketentuan umum Murabahah dalam bank Syariah :

a) Bank dan nasabah harus melakukan akad murabahah yang bebas riba

b) Barang yang diperjualbelikan tidak diharamkan oleh Syariah Islam.

c) Bank membiayai sebagian atau seluruh harga pembelian barang yang telah disepakati kualifikasinya.

d) Bank membeli barang yang diperlukan nasbah atas nama bank sendiri, dan pembelian ini harus sah dan tanpa riba.

e) Bank harus menyampaikan semua hal yang berkaitan dengan pembelian, misalnya jika pembelian dilakukan secara utang.

f) Bank kemudian menjual barang tersebut kepada nasabah (pemesan) dengan harga jual senilai harga beli plus keuntungannya. Dalam kaitan ini bank harus memberitahu secara jujur harga pokok barang kepada nasabah berikut biaya yang diperlukan.

g) Nasabah membayar barang sesuai harga yang disepakati tersebut pada jangka waktu tertentu yang telah disepakati.

h) Untuk mencegah terjadinya penyalahgunaan atau kerusakan akad tersebut, pihak bank dapat mengadakan perjanjian khusus dengan nasabah.

i)Jika bank hendak mewakilkan kepada nasabah untuk membeli barang dari pihak ketiga, akad 
jual beli murabahah harus dilakukan setelah barang, secara prinsip, menjadi milik bank.

2) Ketentuan Murabahah kepada nasabah:

a) Nasabah mengajukan permohonan dan janji pembelian suatu barang atau asset kepada bank.

b) Jika bank menerima permohonan tersebut, ia harus membeli terlebih dahulu asset yang dipesannya secara sah dengan pedagang.

c) Bank kemudian menawarkan asset tersebut kepada nasabah dan nasabah harus menerima (membeli)-nya sesuai dengan janji yang telah disepakatinya, karena secara hukum janji tersebut mengikat; kemudian kedua belah pihak harus membuat kontrak jual beli.

d) Dalam jual beli ini bank diperbolehkan meminta nasabah untuk membayar uang muka saat menandatangani kesepakatan awal pemesanan.

e) Jika nasabah kemudian menolak membeli barang tersebut, biaya riil bank harus dibayar dari uang muka tersebut.

f) Jika nilai uang muka kurang dari kerugian yang harus ditanggung oleh bank, bank dapat meminta kembali sisa kerugiannya kepada nasabah.

g) Jika uang muka memakai kontrak 'urbun sebagai alternative dari uang muka, maka :

1. Jika nasabah memutuskan untuk membeli barang tersebut, ia tinggal membayar sisa harga.
2. Jika nasabah batal membeli, uang muka menjadi milik bank maksimal sebesar kerugian yagn ditanggungoleh bank akibat pembatalan tersebut; dan jika uang muka tidak mencukupi, nasabah wajib melunasi kekurangannya.

3) Jaminan dalam murabahah:

a) Jaminan dalam murabahah dibolehkan, agar nasabah serius dengan pesanannya

b) Bank dapat meminta nasabah untuk menyediakan jaminan yang dapat dipegang.

4) Utang dalam murabahah:

a) Secara prinsip, penyelesaian utang nasabah dalam transaksi murabahah tidak ada kaitannya dengan transaksi yang dilakukan nasabah dengan pihak ketiga atas barang tersebut. Jika nasabah menjual kembali barang tersebut dengan keuntungan atau kerugian, ia tetap berkewajiban untuk menyelesaikan utangnya kepada bank.

b) Jika nasabah menjual barang tersebut sebelum masa angsuran berakhir, ia tidak wajib segera melunasi seluruh angsurannya.

c) Jika penjualan barang tersebut menyebabkan kerugian, nasabahtetap harus menyelesaikan utangnya sesuai kesepakatan awal. Ia tidak boleh memperlambat pembayaran angsuran atau meminta kerugian itu diperhitungkan.

5) Penundaan pembayaran dalam murabahah:

a) Nasabah yang mempunyai kemampuan tidak dibenarkan 
menunda penyelesaian utangnya.

b) Jika nasabah menunda-nunda pembayaran dengan sengaja, atau jika salah satu pihak tidak menunaikan kewajibannya, maka penyelesaiannya dilakukan melalui Badan Arbitrasi Syariah setelah tidak tercapai kesepakatan melalui musyawarah.

6) Bangkrut dalam murabahah:

Jika nasabah telah dinyatakan pailit dan gagal menyelesaikan utangnya, bank harus menunda tagihan utang sampai ia menjadi sanggup kembali, atau berdasarkan kesepakatan.

Pemaparan diatas adalah ketentuan murabahahah sesuai fatwa DSN MUI yang menjadi rujukan dalam penelitian ini apakah praktik murabahah yang diterapkan di warung mikro bank Syariah mandiri Bojonegoro sesuai atau tidak sesuai dengan fatwa tersebut.

Dalam transaksinya murabahah ada 2 jenis yaitu murabahah berdasarkan pesanan yaitu penjual melakukan pembelian barangsetelah ada pesanan dari pembeli dan murabahah tanpa pesanan yaitu penjual menyediakan barang tanpa menunggu ada pesanan dari pembeli. ${ }^{8}$

Adapun Rukun dan Syarat Murabahah dalam perbankan yaitu :

1) Pihak Yang berakad (Al-'aqidain)
a) Penjual : Bank
b) Pembeli : Nasabah
c) Pemasok : Supplier

2) Obyek yang diakadkan (Mahallul' Aqad)

\footnotetext{
${ }^{8}$ Kautsar Riza Salman, Akuntasi Perbankan Syariah Berbasis PSAK Syariah, Jakarta:Akademia Permata, 2014, hlm.145-146
}

a) Adanya Wujud baranga yang diperjualbelikan.

b) Harga Barang

3) Tujuan Akad (Maudhu'ul Aqad)

4) Akad (Sighat al-'aqad)

a) Serah : Ijab

b) Terima : Qabul. ${ }^{9}$

\section{Warung Mikro Bank Syariah Mandiri}

Warung Mikro Bank Syariah Mandiri adalah segmentasi khusus Bank Syariah Mandiri yang mengelola pembiayaan yang ditujukan kepada nasabah wiraswasta atau pedagang dengan fasilitas pembiayaan sampai dengan Rp. $200.000 .000 .{ }^{10}$ Pembiayaan mikro ini bertujuan untuk memberikan bantuan modal untuk pedagang kecil dan menengah. Dalam perkembangannya warung mikro BSM tidak hanya melayani pembiayaan modal kerja saja,akan tetapi juga pembiayaan multi guna untuk kebutuhan investasi ataupun konsumtif. Sasaran nasabah pun semakin melebar karena tidak hanya pedangan ataupun wiraswasta akan tetapi juga nasabah dengan sumber pembayran berasal dari gaji/ peghasilan yang diterima setiap bulan disebut golongan penghasilan tetap (golbertap), contohnya PNS, pegawai BUMN, pegawai BUMD, TNI/POLRI, maupun pegawai perusahaan swasta yang didirikan sesuai peraturan perundangundangan yang berlaku.

\section{METODE PENELITIAN}

Jenis penelitian ini adalah penelitian kualitatif dengan pendekatan studi kasus sehingga dapat mengetahui

\footnotetext{
${ }^{9}$ Divisi Pengembangan Produk dan Edukasi Departemen Perbankan Syariah Otoritas Jasa Keuangan. 2016. Standar Produk Perbankan Syariah Murabahah. Jakarta.OJK

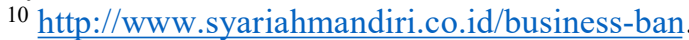
king/micro-banking/pembiayaan-usaha-mikro , Diakses Hari Kamis 05 Maret 2020, Pukul 13.33 WIB
} 
bagaimana

Implementasi

pembiayaan murabahah yang sebenarbenarnya. Peneliti melihat kepada sistem dan pelaksanaan akad murabahah pada Bank Syariah Mandiri terhadap fatwa Dewan Pengawas Syariah MUI No.4/DSN-MUI/III/2000 tentang Murabahah. Penelitian di fokuskan pada sistem pembiayaan murabahah dan pelaksanaan murabahah pada Bank Syariah Mandiri segmen Warung Mikro cabang Bojonegoro. Sehingga dari penelitian tersebut peneliti mengetahui tentang pembiayaan murabahah pada warung mikro bank syariah mandiri cabang bojonegoro sesuai atau tidak dengan fatwa DSN MUI maupun prinsip syari'ah yang berlaku. Penelitian ini menggunakan metode Triangulasi untuk memeriksa dan menetapkan validitas dengan menganalisa dari perspektif.

Penelitian ini dilaksanakan di BSM KC Bojonegoro pada bulan 02 Januari - 31 Juli 2020.

Sumber data penelitian ini diperoleh dari hasil wawancara terstruktur kepada marketing pembiayaan mikro BSM Bojonegoro atas nama Ahmad Robeh Sentosa dan Dennys Prasmana Adi, kemudian wawancara di lanjutkan kepada mikro financing analis BSM Bojonegoro atas nama Amir Ma'mun, dari bagian operasional wawancara dilakukan dengan bapak Rama Abdullah Rahmat Akbar sebagai supervisor operasional BFO Bojonegoro. Analisis data dalam penelitian ini dilakukan dengan mereduksi data hasil temuan di lapangan menjadi data-data yang penting dan dibutuhkan dalam penelitian, hasil reduksi data disajikan dalam bentuk teks yang bersifat naratif, dari hasil pemaparan dan penyajian data diambil kesimpulan akhir dari hasil penelitian.

\section{HASIL DAN PEMBAHASAN}

\section{Implementasi Murabahah pada warung mikro bank Syariah Mandiri Bojonegoro.}

Bank Syariah Mandiri Bojonegoro merupakan salah satu Bank Syariah pertama di Bojonegoro dan memiliki peran penting sebagai penyedia kebutuhan masyarakat Bojonegoro, terutama dalam hal financial secara Syariah. Bank Syariah mandiri sering dikenal di masyarakat dengan sebutan bank haji, dikarenakan masyarakat Bojonegoro identik jika pendaftaran haji selalu ke bank Syariah mandiri. Produk lain dari bank Syariah mandiri adalah warung mikro bank Syariah mandiri yang sudah dijabarkan diatas merupakan salah satu produk yang ditawarkan untuk membantu kebutuhan masyarakat terutama untuk UMKM disekitar wilayah bank Syariah mandiri Bojonegoro untuk mengembangkan usahanya. Seiring dengan perkembangan warung mikro bank Syariah mandiri tidak hanya memproses pembiayaan untuk UMKM saja tetapi juga merambah kepada masyarakat sekitar yang memiliki penghasilan tetap (Golbertap) atau pegawai untuk memenuhi kebutuhannya, seperti kepemilikan kendaraan maupun untuk renovasi rumah.

Warung mikro bank Syariah mandiri menggunakan akad Murabhah untuk menyalurkan pembiayaan kepada nasabah, dengan berpedoman fatwa DSN No: 04/DSN-MUI/IV/2000 tentang Pembiayaan Murabahah dan Implementa si pembiayaan murabahah. Implikasi dengan menggunakan akad murabahah adalah bank bertindak sebagai penjual nasabah bertindak sebagai pembeli dan adanya barang yang diperjual belikan. Bank menyediakan barang pesanan nasabah terlebih dahulu yang kemudian dijual kepada nasabah dengan akad murabahah, dengan menyebutkan harga 
perolehan barang ditambah keuntungan yang diinginkan oleh bank kepada nasabah.

Praktik pembiayaan Murabahah pada warung mikro bank Syariah mandiri bojonegoro menggunakan akad wakalah sebagai pendamping akad murabahah,seperti yang di sampaikan oleh bapak Rama abdullah Rahmat Akbar dalam wawancara "warung mikro BSM Bojonegoro menggunakan akad murabahah untuk pembiayaan, selain itu juga melengkapi akad murabahah dengan akad wakalah kepada nasabah yaitu memberikan kuasa kepada nasabah untuk membeli barang sesuai kesepakatan yang telah ditentukan diawal."11 Dengan akad wakalah bank tidak menyerahkan barang kepada nasabah akan tetapi menyerahkan dana untuk membeli barang yang dibutuhkan nasabah sebagai objek murabahah. Bank meskipun sudah menyerahkan kuasa kepada nasabah melalui akad wakalah untuk membeli barang objek murabahah, bank tetap melakukan pengawasan terhadap barangbarang yang akan dibeli oleh nasabah, supaya tidak keluar dari koridor kesepakatan barang yang telah dilakukan maupun terjadinya sidestreaming pembiayaan yaitu penggunaan dana yang tidak sesuai dengan akad. Praktik warung mikro bank Syariah mandiri menggunakan mekanisme murabahah yang dapat dijelaskan prosesnya sebagai berikut :

a. Nasabah dan Bank saling bernegosiasi untuk memenuhi kebutuhan

b. Bank dan nasabah melakukan akad murabhah dengan spesifikasi barang yang telah ditentukan

c. Bank memberikan kuasa atau akad wakalah kepada nasabah

11 Rama Abdulllah Rahmat Akbar, BFO Supervisor, wawancara, Bojonegoro, 23 Juli 2020 untukmembeli barnag-banrang sesuai dengan kesepakatan yang tercantum di akad murabahah.

d. Nasabah membeli barang kepada pemasok atas nama bank berdasarkan akad wakalah yang sudah disepakati.

e. Pemasok mengirim barang kepada nasabah

f. Nasabah menerima barang dan bukti-bukti pembelian dari pemasok

g. Nasabah menyerahakan kwitansi dan bukti pembelian kepada bank sebagai bukti telah melaksanakan pembelian barang sesuai akad yang disepakati.

h. Nasabah membayar angsuran tiap bulannya sampai waktu yang ditentukan sesuai kesepakatan.

\section{Prosedur Pembiayaan Warung Mikro PT. Bank Syariah Mandiri}

Penelitian yang telah dilakukan yaitu dengan pengamatan dan wawancara terhadap informan yaitu bapak Dennys Prasmana Adi Riteil Sales Executive dan Bapak Amir Ma'mun Mikro Financing Analis BSM Bojonegoro $^{12}$ dapat diketahui prosedur pembiyaan pada warung mikro bank syariah mandiri cabang Bojonegoro adalah sebagai berikut :

\section{a. Pengajuan permohonan pembiayaan.}

1) Calon nasabah mengisi formulir aplikasi permohonan pembiayaan dengan lengkap

12 Dennys Prasmana Adi dan Amir Ma'mun, RSE dan MFA, wawancara, 23 Juli 2020. 
2) Aplikasi pembiayaan diserahkan dengan melampirkan data pendukung seperti KTP, kartu keluarga, surat nikah, NPWP, surat keterangan usaha, laporan keuangan dan fotokopi agunan. Jika nasabah adalah golongan berpenghasilan tetap ( GOLBERTAP) dapat di lampirkan fotokopi SK pegawai, slip gaji 3 bulan terakhir, dan mutasi rekening selama 3 bulan.

3) Marketing mikro disebut Ritail Sales Executive (RSE) menerima berkas pengajuan pembiayaan dari nasabah dan memastikan kelengkapan berkas pengajuan.

b. Verifikasi, Appraisal dan Analisa Pembiayaan.

1) Proses awal $R S E$ membuat permohonan kepada operatioanal untuk melakukan iDEB (Informasi Debitur dari OJK).

2) Jika hasil $i D E B$ terdapat catatan bahwa calon nasabah memiliki riwayat pembayaran yang tidak lancar di bank lain, RSE menyampaikan kepada nasabah pengajuan pembiayaan ditolak.

3) Jika hasil $i D E B$ baik $R S E$ melengkapi berkas kemudian dilanjutkan penyerahan berkas kepada Micro Financing Analys (MFA).

4) Mikro Financing Analys (MFA) malakukan scoring melalui aplikasi Financing Approval Sistem (FAS) dengan hasil apakah nasabah "direkomendasikan" atau "tidak direkomendasikan".

5) Apabila hasil scoring direkomendasikan MFA mengunjungi nasabah untuk melakukan cek dan ricek nasabah beserta usaha dan agunannya

6) Dari hasil kunjungan MFA melakukan penilaian atas karakter calon nasabah, kelayakan usaha apakah layak untuk dibiayai dari penilaian pengelolaan calon nasabah terhadap usahanya, hasil dari usaha apakah dapat mencukupi untuk pembayaran angsuran.

7) MFA menaksir harga dari agunan yang diserahkan

Setelah diyakini bahwa nasabah layak untuk dibiayai $M F A$ melakukan analisa dan pembuatan Nota Analisa Pembiayaan (NAP) melalui aplikasi FAS dan diajukan ke pemutus pembiyaan yaitu Branch Manager (BM).

\section{c. Persetujuan Pembiayaan.}

1) Berdasarkan usulan $M F A$ pada aplikasi FAS branch manager menganalisa dan menimbang usulan.

2) Jika banch manager menolak usulan pembiayaan maka di buatkan surat penolakan kepada nasabah.

3) Jika usulan pembiayaan disetujui oleh branch manager RSE membuat Surat Penawaran Pemberian Pembiayaan (SP3) yang berisi syarat-syarat yang harus dipenuhi sebelum pembiyaan terealisasi yang harus di tandatangai dan disetujui oleh nasabah.

\section{d. Akad Pembiayaan}

1) Dengan terbitnya SP3 yang telah ditandatangani nasabah dan telah diserahkan kembali kepada pihak bank, Branch Financing 
Operational (BFO) membuatkan akad pembiayaan.

2) Penandatanganan akad dilakukan dihadapan notaris dengan proses pengikatan agunan.

3) Nasabah menyediakan biayabiaya untuk administrasi, premi asuransi, pengikatan agunan dan biaya lain yang dipersyaratkan.

\section{e. Proses Realisasi pembiyaan.}

1) Setelah proses akad dilakukan berkas pembiayaan di serahkan kepada unit Branch Financing Operational (BFO) dan dilakukan cek dan ricek lebih mendalam tentang kelengkapan berkas dan kesesuaian dokumen yang diserahkan. Jika ada dokumen yang masih ada kekurangan Financing operation Staff (FOS) menyampaikan kepada $R S E$ untuk dipenuhi.

2) Apabila dokumen pembiayan sudah dinyatakan Comply bisa dilanjutkan proses posting ke sistem untuk realisasi pembiyaan ke rekening nasabah.

3) Setelah dana masuk kerekening nasabah, bisa dilakukan penarikan dana dan wajib digunakan untuk pembelian barang oleh nasabah untuk memenuhi kebutuhan yang telah di sepakati pada akad pembiayaan atas nama bank berdasarkan akad wakalah yang telah di tandatangani.

4) Dokumen pembiayaan, seperti : Nota Analisa Pembiayaan (NAP), Surat Penawaran Pembiayaan (SP3), Akad Pembiayaan, agunan dan pengikatannya, dan dokumendokumen lain yang terkait pembiyaan di simpan rapi oleh $B F O$.

\section{f. Administrasi Pembiayaan}

1) Nasabah melakukan pembayaran angsuran sesuai kesepakatan tiap bulannya dengan menyetorkan ke rekening nasabah.

2) Pendebetan angsuran dilakukan secara otomatis (auto debet) oleh sistem sesuai tanggal yang telah dijadwalkan.

3) Pendebetan angsuran pada rekenign nasabah dilakukan berdasarkan surat kuasa pendebetan yang diberikan oleh nasabah kepada pihak bank bersamaan dengan kelengkapan berkas akad.

Hasil pengamatan dan wawancara mengenai prosedur pembiayaan warung mikro dinilai dari fatwa DSN MUI dapat disimpulkan sudah sesuai, yaitu secara alur merupakan murabahah berdasarkan pesanan. Nasabah memesan barang-barang yang dibutuhkan kepada bank yang disebutkan dalam prosesdur di atas sebagai permohonan nasabah dan melengkapi semua persyaratan yagn dibutuhkan, baru kemudian bank menyediakan barang pesanan melalui supplier.

\section{Analisis \\ Kesesuaian \\ Implementasi Murabahah Warung Mikro Bank Syariah Mandiri Cabang Bojonegoro.}

Penggunaan murabahah untuk modal kerja pada Warung Mikro Bank Syariah Mandiri dilakukan karena memiliki kemudahan dan beberapa keuntungan sebagai berikut :

1. Mempermudah dalam hubungan antara nasabah dan bank, karena 
bersifat jual beli. halnya jika pembiayaan menggunakan akad mudharabah atau musyarakah, karena nasabah harus melaporkan keuangan setiap bulannya ke bank.

2. Nasabah mengetahui semua biaya yang dibutuhkan, mulai dari harga pokok barang dan keuntungan yang diambil oleh bank.

3. Objek murabahah adalah barang yang dibeli.

4. Pembayaran dilakukan secara angsuran.

Dari uraian diatas tentang implementasi dan prosedur murabahah yang dijalankan di warung mikro bank Syariah mandiri dapat dianalisa lebih mendalam.

a. Akad Murabahah

Bagian akad untuk mengetahui isi dari akad pembiayaan murabahah, warung mikro bank syariah mandiri Bojonegoro menggunakan template akad dari Kantor Pusat yang terdiri dari 8 Pasal dan diperkuat dengan lampiran-lampiran tambahan termasuk akad wakalah dan purchase order. 8 pasal tersebut adalah :

1) Pasal 1 Definisi dan Interpretasi

2) Pasal 2 Pelaksanaan Pembiayaan Murabahah

3) Pasal 3 Syarat Realisasi Pembiayaan

4) Pasal 4 Pokok Akad, Biaya, Obyek Akad, dan Jangka Waktu Pembiayaan

5) Pasal 5 Jaminan

6) Pasal 6 Kuasa
7) Pasal 7 Pemberitahuan

8) Pasal 8 Penutup

Menjadi bagian dari akad tersebut lampiran berupa form permohonan nasabah, Akad Wakalah, Purchase Order, Surat Tanda Terima Barang.

b. Pemenuhan Rukun dan Syarat pada Akad Warung Mikro Bank Syariah Mandiri Bojonegoro.

Dari akad pemenuhan rukun akad adalah sebagai berikut :

1) Penjual adalah Warung mikro bank Syariah mandiri diwakili oleh kepala cabang Bojonegoro

2) Pembeli adalah nasabah

3) Barang (obyek murabahah) adalah lampiran barnag yang dibeli

4) Harga barang (termasuk keuntungan) ada di bab 4 akad

5) Sighat akad murabahah adalah kedua belah pihak sepakat malakukan perjanjian dengan memahami isi perjanjian dengan menandatangi akad.

Dari akad sudah terpenuhi tentang rukun dan syarat, dapat di simpulkan akad pembiayaan murabahah pada warung mikro bank Syariah mandiri bojonegoro sesuai dan sah. 
4. Analisis

Kesesuaian

Implementasi

Murabahah

Warung Mikro Bank Syariah

Mandiri Cabang Bojonegoro

dengan Fatwa DSN no: 04/DSN-

MUI/IV/2000

tentang

Murabahah.

Analisa selanjutnya dilakukan dengan menganalisis kesesuaian implementasi Murabahah Warung Mikro Bank Syariah Mandiri Bojonegoro dengan fatwa DSN MUI No: 04/DSN-MUI/VI/2000 yang sudah di jabarkan di bab 2. Penulis sering mendengar tuduhan-tuduhan tentang bank Syariah yang sama saja dengan bank konvensional. Apalagi pada proses pembiayaan warung mikro bank Syariah mandiri yang penulis teliti ini, dikarenakan kurangnya Informasi dan ilmu yang dimiliki masyarakat tersebut. Yang diketahui masyarakat awan, nasabah datang ke bank Syariah mandiri Bojonegoro untuk mendapatkan tambahan modal untuk mengembangkan usahanya, kemudian nasabah pulang di berikan dana pembiayaan untuk di belikan barangbarang usaha. Pemahaman seperti itu juga tidak seluruhnya salah, karena memang orang awam ketika melihat keadaan seperti itu yang terlihat. Dengan penelitian ini penulis ingin memberikan gambaran tentang proses yang terjadi dalam pembiayaan murabahah di Warung mikro Bank Syariah Mandiri Bojonegoro.

Dalam fiqh Islam, akad murabahah atau jual beli, penjual harus memiliki barang terlebih dahulu sebelum di transaksikan. Merujuk pada fatwa DSN MUI ketentuan poin 3 yang berbunyi " Bank membiayai sebagian atau seluruh harga pembelian barang yang telah disepakati kualifikasinya". Berdasarkan hasil wawancara dengan bapak Rama Abdullah Rahmat Akbar mengatakan "dalam hal ini warung mikro bank Syariah mandiri Bojonegoro bertindak sebagai penyedia barang dengan cara pesanan, tidak menyediakan atau stok barang sebelum melakukan murabahah dengan nasabah. Bank akan menyediakan barang sesuai pesanan dan spesifikasi yang telah disepakati dengan nasabah."13

Akad yang digunakan pada Warung Mikro bank Syariah mandiri Bojonegoro tidak hanya menggunakan akad murabahah, ${ }^{14}$ akan tetapi juga menggunakan akad wakalah untuk memberikan kewenangan kepada nasabah membeli barang dagang yang dibutuhkan atas nama bank Syariah mandiri Bojonegoro kepada pemasok atau supplier. Merujuk pada Fatwa DSN MUI yang dijabarkan pada bab 2 yaitu ketentuan pertama poin 9 yang berbunyi "Jika bank hendak mewakilkan kepada nasabah untuk membeli barang dari pihak ketiga, akad jual beli murabahah harus dilakukan setelah barang, secara prinsip, menjadi milik bank". Dalam hal kepemilikan barang secara prinsip masih lanjut berdasarkan keterangan bapak Rama (panggilan bapak Rama Abdullah Rahmat Akbar) "di terjemahkan apabila bank telah melakukan konfirmasi pembelian kepada pemasok dengan rincian barang yang telah disepakati, maka secara prinsip barang telah dibeli oleh bank. Walaupun belum ada pembayaran langsung kepada pemasok atau supplier, tetapi bank berkomitmen untuk melakukan pembayaran yang diwakilkan kepada nasabah dengan media akad wakalah."15

Lampiran akad terdapat purchase order dari bank kepada pemasok dengan rincian barang-barang yang akan dibeli atau dibutuhkan oleh nasabah. Sehingga secara prinsip barang-barang yang di beli

13 Rama Abdulllah Rahmat Akbar, BFO

Supervisor, wawancara, Bojonegoro, 23 Juli

2020

14 ibid

$15 \quad$ ibid 
berdasarkan akad wakalah adalah barangbarang milik Bank yang selanjutkan masuk dalam akad murabahah antara bank dengan nasabah.

\section{Analisis Implementasi Murabahah Warung Mikro Bank Syariah Mandiri Cabang Bojonegoro dengan peraturan Otoritas Jasa Keuangan (OJK).}

Untuk saat ini yang mengatur ketentuan hukum positif perbankan di Indonesia adalah Jasa Otoritas Keuangan (OJK). Dalam perkembangan perbankan Syariah terutama pembiayaan murabahah OJK mengeluarkan panduan berupa buku Standar Produk Perbankan Syariah Murabahah yang sedikit telah dijawbarkan di bab 2. Bank Syariah dalam praktik pembiayaan murabahah tidak berperang secara langsung sebagai penjual murni yang memiliki persediaan barang sebelum melakukan akad murabahah dengan nasabah.

Kepemilikan secara prinsip, OJK lebih memperjelas dengan menjabarkan bahwa barang telah dimiliki secara prinsip dengan menyebutkan cirinya yaitu barang tersebut memiliki spesifik yang jelas, mudah diidentifikasi, memiliki nilai, memiliki bukti legal kepemilikan, serta dapat dipindahkan kepemilikannya. Pada akad murabahah warung mikro bank Syariah mandiri terdapat lampiran purchase order yang berisi spesifikasi barang atau obyek yang dibeli kepada supplier atau pemasok, sehingga bisa dinyatakan sesuai dengan manual yang telah di terbitkan oleh OJK.

Tuduhan lain tentang bank Syariah yang tidak sesuai dengan Syariah adalah bank belum memiliki barang tetapi telah mengalihkan kepemilikan barang kepada nasabah. Menanggapi hal ini sesuai yang telah di jelaskan oleh bapak Rama pada wawancara bahwa bank secara prinsip telah memiliki barang yang menjadi objek murabahah. ${ }^{16}$ Diperjelas lagi oleh OJK dalam manual murabahah yaitu Kepemilikan Obyek Pembiayaan sedapat mungkin dialihkan secara efektif dari Bank sebagai Penjual kepada Nasabah sebagai Pembeli sesuai kebiasaan yang berlaku sepanjang tidak bertentangan dengan Syariah. Konsep kepemilikan Obyek Pembiayaan secara efektif yang dimaksud adalah saat kedua belah pihak memasuki dan menyepakati kontrak sah jual beli sekalipun tidak diharuskan adanya bukti legal administrasi kepemilikan oleh Bank (penguasaan fisik). Kepemilikan oleh Bank dianggap sah hanya cukup dengan bukti transaksi antara Bank dan Pemasok (penguasaan konstruktif).

Tuduhan lain yang dialamatkan kepada bank Syariah, khusus pada penelitian ini yaitu warung mikro bank Syariah mandiri Bojonegoro adalah akad murabahah dilaksanakan sebelum barang di beli oleh bank, walaupun pembelian sudah dijalankan dengan akad wakalah. Menanggapai hal tersebut pada manual OJK disebutkan bahwa Dalam hal para pihak ingin melaksanakan akad pembiayaan Murabahah sebelum Nasabah melaksanakan tugas wakalahnya, maka akad Murabahah berlaku efektif setelah melakukan tugas wakalah (muallaq).

Uraian diatas adalah sesuai dengan yang dipraktikan Warung mikro bank Syariah Mandiri Bojonegoro. Jadi secara prosedur dan praktik telah sesuai dengan manual yang di tetapkan oleh OJK.

\section{KESIMPULAN}

Dari penelitian yang dilakukan dapat disimpulkan :

$16 \quad$ ibid 
a. Bahwa alur pembiayaan murabahah modal kerja di warung mikro bank syariah mandiri secara garis besar adalah nasabah mengajukan pembiayaan ke warung mikro bank syariah mandiri kemudian berkas diterima oleh RSE dengan kelengkapannya, selanjutnya berkas dianalisis oleh MFA apakah calon nasabah layak untuk dibiayai atau tidak. Jika nasabah tidak layak dibiayai, pengajuan ditolak dan Jika nasabah layak untuk dibiayai dilanjutkan untuk diusulkan ke pemutus pembiayaan cabang. Nasabah dan bank menandatangai surat penawaran pembiayaan yang dilanjutkan dengan penandatanganan akad wakalah dan akad murabahah.

b. Setelah kelengkapan terpenuhi Bank mencairkan pembiayaan ke rekening nasabah untuk selanjutnya digunakan oleh nasabah membeli barang untuk usaha kepada pemasok yang telah ditunjuk oleh Bank dengan kuasa akad Wakalah sebagai wakil bank. Nasabah menyerahkan bukti pembelian kepada bank setelah menerima barang, selanjutnya Nasabah membayar angsuran pembiayaan setiap bulan sesuai dengan akad yang telah ditandatangi.

c. Dari hasil penelitian yang telah di sampaikan diatas juga dapat disimpulkan, bahwa penerapan akad murabahah pada warung mikro bank syariah mandiri yang banyak digunakan untuk pembiayaan modal kerja telah sesuai dengan fatwa DSN MUI 04/DSN-MUI/IV/2000 tentang Murabahah dan Implementasi Pembiayaan Murabahah. Dalam hal ini bank melakukan pembiayaan murabahah berdasarkan pesanan, jika ada nasabah yang membutuhkan barang- barang untuk memenuhi kebutuhan usahanya baru disediakan oleh Warung Mikro Bank Syariah Mandiri Bojonegoro. Jadi Warung mikro BSM tidak melakukan stok barang. Hasil penelitian ini juga dapat diartikan bahwa fungsi DPS BSM dalam pengawasan dan pengawalan sudah berjalan dengan baik

\section{DAFTAR PUSTAKA}

Bank Syariah mandiri. 2018. Manual Produk Pembiayaan Mikro bank Syariah mandiri. Jakarta

Divisi Pengembangan Produk dan Edukasi Departemen Perbankan Syariah Otoritas Jasa Keuangan. 2016. Standar Produk Perbankan Syariah Murabahah. Jakarta.OJK

Dewan Syariah Nasional, Fatwa Dewan Syariah Nasional No: 04/DSN-MUI/IV/2000 Pembiayaan Murabahah dan Implementasi pembiayaan murabahah

Effasa Ahmad Saifurriza,Furi Asfiayatul Ain. 2019. Faktor-faktor yagn memperngaruhi rendahnya minat pedagang muslim dalam menggunakan jasa bank Syariah mandiri kc Sumberrejo Bojonegoro. Jurnal. Gema Ekonomi Jurnal Fakultas Ekonomi, 8(1). 
Khofsah Sholihatin, Implementasi Pembiayaan Murabahah bil Wakalah Sebagai Upaya untuk Meningkatkan Ekonomi Peternak Sapi di BMT Al-Hijrah Kan Jabung. Tesis. Program Pasca Sarjana Universitas Islam Negeri Maulana Malik Ibrahim Malang tahun 2017

Nurhabibah Desi, Implementasi Akad Murabahah pada Produk Pembiayaan Pertanian di BMT As-Syafi'iyah Kabupaten Pringsewu dan BMT Al- Hasanah Kabupaten Lampung Selatan Dalam perspektif Ekonomi Islam .Tesis . Program Pasca Sarjana Universitas Islam Negeri Raden Intan Lampung Tahun 2018

Ramadhani Kiki Priscilia, Analisis Kesyariahan Penerapan Pembiayaan Murabahah (studi kasus PT. Bank Pembiayaan Rakyat Syariah xxx di Kota Mojokerto). Jurnal. Jurusan Ilmu Ekonomi Fakultas Ekonomi dan Bisnis Universitas Brawijaya Malang tahun 2014.

Yusuf, Muhammad. 2011, Analisis Penerapan Pembiayaan Murabahah Berdasarkan Pesanan dan Tanpa Pesanan Serta Kesesuaian dengan PSAK 102. Jurnal. Jakarta: BINUS Universit.

Anselm Strauss dan Juliet Corbin, Dasar-Dasar Penelitian Kualitatif, (Yogyakarta: Pustaka Pelajar, 2003), h. 4

Antonio, Muhammad Syafi'i. Bank Syariah Dari Teori ke Praktik. Jakarta: Gema Insani Press, 2001.

Anwar, Syamsul. Hukum Perjanjian Syariah Studi Tentang Teori Akad dalam Fikih Muamalat. Jakarta: Rajawali Press, 2010

Ascarya, Akad dan Produk Bank Syariah (Jakarta: PT Raja Grafindo, 2011), 82

Hadi, Abd. Hukum Perbankan Syariah Akad-akad dan Dasar Hukum. Malang. Setara Press, 2018.

Husein Umar, Metode Penelitian; Untuk Skripsi dan Tesisi Bisnis,(Jakarta: Raja Grapindo Persada, 2005), h. 42

Iskandar, Metodologi Penelitian Pendidikan dan Sosial (Kuantitatif dan Kualitatif).(Jakarta: Gaung Persada Press, 2010), h. 77

Ismail. 2010. Perbankan Syariah. Jakarta: Kencana. hal 168.

Kautsar Riza Salman, Akuntasi Perbankan Syariah Berbasis PSAK Syariah, Jakarta:Akademia Permata, 2014, hlm.145-146

Mardani, 2012. Fiqh Ekonomi Syariah : Fiqh Muamalah. Jakarta : Kencana Prenada Media Group

Muhammad Syafi'I Antonio, Bank Syariah: Dari Teori ke Praktek, (Jakarta: Gema Insani, Cet ke-1,2010) hal 90

Muhammad, Manajemen Pembiyaan Bank Syariah, (Yogyakarta: YKPN, 2005), hal 17

Nasroen Haroen, Fiqh Muamalah, Gaya Media Pratama, Jakarta, 2000, hlm. 97 
Sugiyono, Metode Penelitian Pendidikan Pendekatan Kuantitatif Kualitatif dan $R$ dan $D$, (Bandung, Alfabeta, 2010), h. 399

http://www.syariahmandiri.co.id/business-banking/micro-banking/pembiayaan-usahamikro , "Pembiayaan Usaha Mikro".Diakses Hari Kamis 05 Maret 2020, Pukul 13.33 WIB

https://www.mandirisyariah.co.id/tentang-kami/sejarah, "sejarah bank Syariah mandiri" diakses hari Selasa tanggal 2 Juni 2020, pukul 14.40

Akbar, Rama Abdulllah Rahmat, BFO Supervisor, wawancara, Bojonegoro, 23 Juli 2020

Adi, Dennys Prasmana, RSE, wawancara, Bojonegoro, 23 Juli 2020

Ma'mun, Amir, MFA, wawancara, Bojonegoro, 23 Juli 2020

Nugroho, Irawan, Branch Manager, wawancara, Bojonegoro, 24 Juli 2020 